\title{
STUDIES ON THE HISTAMINE SENSITISATION PRODUCED IN MICE BY CORYNEBACTERIUM PARVUM
}

\author{
C. ADLAM \\ Department of Bacteriology, Wellcome Research Laboratories, Beckenham, Kent
}

IT has been known for many years that mice treated with Bordetella pertussis vaccine not only become resistant to challenge with the living organisms but are also sensitised to pharmacological agents and to various stressing treatments. A single injection of suitably grown and killed Bord. pertussis organisms or of "histamine-sensitising factor" extracted from them produces sensitisation to histamine, serotonin, bradykinin, endotoxin, cold shock, X-raysand anaphylaxis. Recent studies suggest that these several sensitising actions of Bord. pertussis are due to a specific action at the level of the $\beta$-receptors of the adrenergic system (Kind, 1958; Fishel, Szentivanyi and Talmage, 1964; Munoz and Bergman, 1968; Arora and Sanyal, 1968; Pieroni et al., 1971), although other mechanisms may be involved (Niwa et al., 1959; Shayer and Ganley, 1961; Gulbenkian et al., 1968).

We have shown recently that killed suspensions of Corynebacterium parvum, a Gram-positive anaerobic organism unrelated to Bord.pertussis but known to possess marked lympho-reticular stimulatory properties (Halpern et al., 1964), are capable of protecting mice from challenge by mouse-virulent Bord. pertussis (Adlam, Broughton and Scott, 1972). In addition, mice treated with C. parvum or closely related diphtheroid species are sensitised to challenge with histamine (Adlam and Scott, 1973).

The purpose of the present work was to compare further the sensitising properties of C. parvum and Bord. pertussis with a view to determining whether the same mechanism is involved.

\section{MATERIALS AND METHODS}

Bacteria. The strain of $C$. parvum used (Wellcome Number CN6134) was originally supplied by Professor M. Raynaud of the Pasteur Institute. Organisms were grown, harvested, killed and dry weights were determined as previously described (Adlam and Scott).

The taxonomic position of $C$. parvum and related diphtheroids has recently been the subject of considerable controversy. Strain CN6134 was originally named $C$. anaerobium, but for the reasons recently outlined by us (Adlam and Scott) and because it is doubtful whether C. anaerobium should be listed as a distinct species (Johnson and Cummins, 1972), it will be referred to here as C. parvum.

The strain of Bord. pertussis used (Wellcome Number CN2992) was from a single routine formalised batch of vaccine provided by $\mathrm{Mr} \mathrm{H}$. K. Favelle of these laboratories. Organisms were suspended in physiological saline containing 0.01 per cent. thiomersalate as preservative.

Received 31 Oct. 1972; revised version accepted 21 Mar. 1973.

J. MRD. MiCROBIOL.-VOL. 6 (1973) 
Mice. Except where indicated, mice were adult females weighing $16-20 \mathrm{~g}$. The following inbred strains were used:

N.I.H. (reared and maintained at Wellcome Research Laboratories).

CBA (Animal Supplies Ltd, Roebuck Farm, Pottersheath, Welwyn, Herts.).

Balb C (Olac House, Blackthorn, Bicester, Oxon.; adult females were 12-14 g).

The following random-bred strains were used:

C.D-1 Cobs (Charles River, 76 Saint-Aubin-les-Elbeuf, Seine-Maritime, France).

Evans/1 (Evans Ltd, Evans Corner, Woodmansterne Lane, Carshalton, Surrey; adult females were $26-30 \mathrm{~g}$ ).

Olac (Olac House).

Bromfield (Bromfield Ltd, 81 Windsor Avenue, Newton Abbot).

Histamine sensitisation. Except where indicated, groups of ten mice received a standard intravenous (i.v.) sensitising dose of $C$. parvum (1.4 mg dry weight) or of Bord. pertussis $(0.22 \mathrm{mg}$ dry weight) and were intraperitoneally (i.p.) challenged 7 days later with varying doses of histamine phosphate (B.D.H. Ltd, Poole, Dorset) expressed as $\mathrm{mg}$ histamine. Survivors were recorded at $24 \mathrm{hr}$.

Serotonin sensitisation. Groups of ten mice received a standard i.p. sensitising dose of C. parvum ( $3.5 \mathrm{mg}$ dry weight) or of Bord. pertussis ( $0.55 \mathrm{mg}$ dry weight) and were challenged i.p. 4 days later with varying doses of serotonin creatinine sulphate (Koch-Light Laboratories Ltd, Colnbrook, Bucks) expressed as mg serotonin. Survivors were recorded at $24 \mathrm{hr}$.

Anaphylactic sensitisation. Groups of ten mice received an i.v. dose of C. parvum $(1.4 \mathrm{mg}$ dry weight) or of Bord. pertussis $(0.22 \mathrm{mg}$ dry weight) at varying time intervals before, after, or in combination with an i.v. priming injection of antigen. Fourteen days after the priming dose of antigen a larger sensitising dose of the same antigen was administered i.p. and survivors were recorded at $24 \mathrm{hr}$. The two sensitising antigens employed were twice-crystallised chicken ovalbumin (Koch-Light Laboratories Ltd) and horse serum no. 2 (Wellcome Reagents Ltd, Beckenham, Kent). For ovalbumin, the priming dose, dissolved in $0.2 \mathrm{ml}$ of physiological saline, was $0.2 \mathrm{mg}$ per mouse; the sensitising dose, dissolved in $0.5 \mathrm{ml}$ saline, was $1.0 \mathrm{mg}$ per mouse. For horse serum, the priming dose was $0.2 \mathrm{ml}$ of serum diluted 1 in 5 in physiological saline, and the sensitising dose was $\mathbf{0 . 2} \mathrm{ml}$ of undiluted serum.

\section{RESULTS \\ Effect of route of $C$. parvum injection on sensitisation to histamine}

Table I shows the results of an experiment in which the effect of route of administration of $C$. parvum on subsequent sensitisation to histamine was examined. Since previous experiments (Adlam, Broughton and Scott; Adlam and Scott) had shown that peak sensitisation to histamine occurred 7 days after C. parvum treatment, this time period was used for the experiment. Mice were most sensitised when $C$. parvum was injected i.v. or i.p. Subcutaneous injection produced only marginal sensitisation.

\section{C. parvum sensitisation to histamine in different mouse strains}

Since the ability of Bord. pertussis to sensitise has been shown to be strongly dependent on the strain of mouse under test (Bergman and Munoz, 1968; Wardlaw, 1970), different strains were compared quantitatively for histamine sensitisation using C. parvum and Bord. pertussis separately (tables II and III). Whereas N.I.H. and Bromfield mice showed a high degree of sensitisation with Bord. pertussis or $C$. parvum at low levels of histamine challenge, CBA mice were only sensitised to high levels of histamine challenge. CD-1 and Olac mice were poorly sensitised by both organisms and Evans/1 mice not at all. Balb C 
mice were sensitised to some extent by Bord. pertussis but were unaffected by C. parvum. As a result of their small mature size, these mice would tolerate only

TABLE I

Effect of route of injection of C. parvum on sensitisation to histamine*

\begin{tabular}{|c|c|c|c|c|}
\hline \multirow{2}{*}{$\begin{array}{l}\text { Challenge dose } \\
\text { of histamine } \\
\text { (mg) }\end{array}$} & \multicolumn{4}{|c|}{$\begin{array}{l}\text { Number of survivors per group of nine or ten mice challenged at } \\
7 \text { days after receiving } C \text {. parvum or saline (control) by the stated } \\
\text { route }\end{array}$} \\
\hline & Intravenous & Intraperitoneal & Subcutaneous & $\begin{array}{c}\text { Saline } \\
\text { intravenous }\end{array}$ \\
\hline $\begin{array}{l}5 \\
1 \\
0 \cdot 5 \\
0.25\end{array}$ & $\begin{array}{l}1 \dagger \\
1 \dagger \\
0\end{array}$ & $\begin{array}{l}0 \\
0 \\
1 \\
2\end{array}$ & $\begin{array}{l}3 \\
3 \dagger \\
7 \\
10\end{array}$ & $\begin{array}{r}8 \\
7 \\
10 \\
10\end{array}$ \\
\hline
\end{tabular}

* Female adult N.I.H. mice received a single injection of killed $C$. parvum $(1.4 \mathrm{mg})$ by different routes and were intraperitoneally challenged at 7 days with the stated doses of histamine. Survivors were recorded at $24 \mathrm{hr}$.

$\dagger$ Only nine mice in this test group.

$\ldots=$ Not done.

TABLE II

A quantitative comparison of C. parvum and Bord.pertussis sensitisation to histamine with three different inbred mouse strains*

\begin{tabular}{|c|c|c|c|c|}
\hline \multirow[t]{2}{*}{ Mouse strain } & \multirow{2}{*}{$\begin{array}{l}\text { Challenge dose } \\
\text { of histamine } \\
\text { (mg) }\end{array}$} & \multicolumn{3}{|c|}{$\begin{array}{l}\text { Number of survivors per group of ten mic } \\
\text { given the stated agent intravenously and } \\
\text { challenged with histamine at } 7 \text { days }\end{array}$} \\
\hline & & Bord. pertussis & C. parvum & Saline \\
\hline C.B.A. & $\begin{array}{c}20 \\
10 \\
5 \\
1 \\
0.5\end{array}$ & $\begin{array}{r}0 \\
2 \\
9 \\
10 \\
10\end{array}$ & $\begin{array}{r}0 \\
0 \\
8 \\
10 \\
10\end{array}$ & $\begin{array}{r}0 \\
10 \\
10 \\
10 \\
10\end{array}$ \\
\hline N.I.H. & $\begin{array}{l}5 \\
1 \\
0.5 \\
0.25 \\
0.1\end{array}$ & $\begin{array}{l}0 \\
0 \\
0 \\
2 \\
9\end{array}$ & $\begin{array}{l}1 \\
1 \\
0 \\
0 \\
0\end{array}$ & $\begin{array}{r}10 \dagger \\
7 \\
3 \\
10 \\
10\end{array}$ \\
\hline Balb C & $\begin{array}{l}20 \\
10 \\
5 \\
1 \\
0.5\end{array}$ & $\begin{array}{r}0 \\
4 \\
8 \\
10 \\
10\end{array}$ & $\begin{array}{l}0 \ddagger \\
10 \\
10 \\
10 \\
10\end{array}$ & $\begin{array}{r}0 \\
10 \\
10 \\
10 \\
10\end{array}$ \\
\hline
\end{tabular}

* Female adult mice of the stated strains (see Methods) received a single intravenous injection of killed Bord. pertussis $(0.22 \mathrm{mg})$ or C. parvum $(1.4 \mathrm{mg})$ and were intraperitoneally challenged at 7 days by varying doses of histamine phosphate (expressed as $\mathrm{mg}$ histamine base). Survivors were recorded at $24 \mathrm{hr}$ as the majority of deaths occurred within that time.

t Bimodal response to histamine observed in this group (see text).

$\ddagger$ As these mice were small, this group received $0.7 \mathrm{mg}$ of $C$. parvum.

a $0.7-\mathrm{mg}$ dose of $C$. parvum. Nevertheless, in experiments in which survivors of the full dose were challenged with histamine, no sensitisation was observed. 
Effect of mouse age on degree of sensitisation by C. parvum

C. parvum sensitisation to histamine was strongly dependent on the age of mouse used. Table IV shows the results of an experiment in which mice of varying ages were tested. Older mice were sensitised to a much greater extent

TABLE III

A quantitative comparison of C. parvum and Bord. pertussis sensitisation to histamine with four different random-bred mouse strains*

\begin{tabular}{|c|c|c|c|c|}
\hline \multirow[t]{2}{*}{ Mouse strain } & \multirow{2}{*}{$\begin{array}{l}\text { Challenge dose } \\
\text { of histamine } \\
\text { (mg) }\end{array}$} & \multicolumn{3}{|c|}{$\begin{array}{l}\text { Number of survivors per group of ten mice } \\
\text { given the stated agent intravenously and } \\
\text { challenged with histamine at } 7 \text { days }\end{array}$} \\
\hline & & Bord. pertussis & C. parvum & Saline \\
\hline CD-1 & $\begin{array}{l}20 \\
10 \\
5 \\
1 \\
0.5\end{array}$ & $\begin{array}{l}1+ \\
7 \\
3 \\
8 \\
9\end{array}$ & $\begin{array}{c}1 \\
8 \\
9 \\
9 \\
\ldots\end{array}$ & $\begin{array}{r}1 \\
10 \\
10 \\
10 \\
10\end{array}$ \\
\hline Evans/1 & $\begin{array}{r}30 \\
20 \\
10 \\
5 \\
1\end{array}$ & $\begin{array}{r}1 \\
6 \\
10 \\
10 \\
9\end{array}$ & $\begin{array}{r}4 \\
5 \\
10 \\
10 \\
10\end{array}$ & $\begin{array}{r}3 \\
7 \\
9 \\
10 \\
10\end{array}$ \\
\hline Olac & $\begin{array}{r}30 \\
20 \\
10 \\
5 \\
1\end{array}$ & $\begin{array}{r}0 \\
3 \\
8 \\
10 \\
9\end{array}$ & $\begin{array}{r}0 \\
6 \\
9 \\
10 \\
10\end{array}$ & $\begin{array}{r}1 \\
9 \\
10 \\
10 \\
10\end{array}$ \\
\hline Bromfield $\ddagger$ & $\begin{array}{r}20 \\
10 \\
5 \\
1\end{array}$ & $\begin{array}{l}\cdots \\
\cdots \\
\cdots \\
1\end{array}$ & $\begin{array}{l}\dddot{1} \\
1 \\
0\end{array}$ & $\begin{array}{r}0 \\
10 \\
10 \\
8\end{array}$ \\
\hline
\end{tabular}

* Female adult mice of the stated strains (see Methods) received a single intravenous injection of killed Bord. pertussis $(0.22 \mathrm{mg})$ or $C$. parvum $(1.4 \mathrm{mg})$ and were intraperitoneally challenged at 7 days by varying doses of histamine phosphate (expressed as mg histamine base). Survivors were recorded at $24 \mathrm{hr}$.

$\dagger$ Bimodal response to histamine observed in this group (see text).

¥ Since Jan. 1972, this strain of mouse as supplied from the breeder has lost sensitising activity. Breeding stock retained in these laboratories remains sensitive.

$\ldots=$ Not done.

than younger ones. This picture was consistently observed with both Bromfield and NIH mouse strains.

\section{Bimodal response to histamine}

Results shown in tables III and IV demonstrate that mice treated with $C$. parvum or Bord. pertussis may respond in a bimodal way to histamine challenge. (Animals that received higher doses of histamine survived better than animals that received lower doses.) Untreated animals may also occasionally show this phenomenon (table II). 
TABLE IV

The effect of mouse age on the degree of histamine-sensitisation produced by $C$. parvum*

\begin{tabular}{|c|c|c|c|}
\hline \multirow[t]{2}{*}{$\begin{array}{l}\text { Age of mice } \\
\text { (weeks) }\end{array}$} & \multirow[t]{2}{*}{$\begin{array}{l}\text { Challenge dose of } \\
\text { histamine (mg) }\end{array}$} & \multicolumn{2}{|c|}{$\begin{array}{l}\text { Number of survivors per group of ten } \\
\text { mice given the stated agent intravenously } \\
\text { and challenged with histamine at } 7 \text { days }\end{array}$} \\
\hline & & C. parvum & Saline \\
\hline $5-6$ & $\begin{array}{r}20 \\
10 \\
5 \\
1\end{array}$ & $\begin{array}{c}0 \dagger \\
10 \\
8 \\
3\end{array}$ & $\begin{array}{c}1 \ddagger \\
6 \\
10 \\
9\end{array}$ \\
\hline $7-8$ & $\begin{array}{r}20 \\
10 \\
5 \\
1\end{array}$ & $\begin{array}{l}0 \dagger \\
2 \\
7 \\
3\end{array}$ & $\begin{array}{l}2 \\
9 \\
9 \\
7\end{array}$ \\
\hline $10-11$ & $\begin{array}{c}20 \\
10 \\
5 \\
1 \\
0.5\end{array}$ & $\begin{array}{l}\dddot{1} \\
1 \\
0 \\
1 \ddagger\end{array}$ & $\begin{array}{r}0 \\
10 \\
10 \\
8 \\
\ldots\end{array}$ \\
\hline $15-16$ & $\begin{array}{c}10 \\
5 \\
1 \\
0.5\end{array}$ & $\begin{array}{l}0 \\
1 \\
1 \\
0\end{array}$ & $\begin{array}{c}8 \\
8 \\
9 \\
\ldots\end{array}$ \\
\hline
\end{tabular}

* Female Bromfield mice received a single intravenous injection of killed C. parvum $(1.4 \mathrm{mg})$ and were intraperitoneally challenged at 7 days with histamine. Survivors were recorded at $24 \mathrm{hr}$.

$\dagger$ Bimodal response to histamine observed in these groups (see text).

¥Only 9 mice in this test group.

$\ldots=$ Not done.

\section{TABLE V}

Aquantitative comparison of C. parvum and Bord.pertussis sensitisation to serotonin in two strains of mice*

\begin{tabular}{l|c|ccc}
\hline Mouse strain & $\begin{array}{c}\text { Challenge dose } \\
\text { of serotonin } \\
\text { (mg) }\end{array}$ & $\begin{array}{c}\text { } \\
\text { chamber of survivors out of number of mice } \\
\text { chatenged at 4 days after receiving the stated } \\
\text { agent intraperitoneally }\end{array}$ \\
\hline N.I.H. & 5 & $3 / 7 \dagger$ & $3 / 10$ & $10 / 10$ \\
& 2 & $1 / 8 \dagger$ & $5 / 9$ & $10 / 10$ \\
Bromfield & 1 & $5 / 7 \dagger$ & $8 / 10$ & $10 / 10$ \\
& 5 & $1 / 10$ & $9 / 10$ & $8 / 10$ \\
& 2 & $0 / 10$ & $10 / 10$ & $10 / 10$ \\
& 1 & $3 / 10$ & $10 / 10$ & $10 / 10$ \\
\hline
\end{tabular}

* Female adult mice received a single intraperitoneal injection of killed Bord. pertussis $(0.55 \mathrm{mg})$ or C. parvum $(3.5 \mathrm{mg})$. Four days later animals were challenged with serotonin creatinine sulphate (expressed as mg serotonin). Survivors were recorded at $24 \mathrm{hr}$, the majority of deaths occurring within $2 \mathrm{hr}$.

$\dagger$ Some deaths occurred in this group of animals following Bord. pertussis treatment. 


\section{Sensitisation of mice to serotonin by $C$. parvum}

In addition to being sensitised by $C$. parvum to histamine, NIH mice were sensitised to serotonin (table V). Surprisingly, $C$. parvum-induced sensitisation to serotonin could not be demonstrated with Bromfield mice, even though these animals were readily sensitised in the same experiment to serotonin by Bord. pertussis. Serotonin sensitisation could not be elicited by either $C$. parvum or Bord. pertussis in either mouse strain when the bacteria were injected i.v.

\section{TABLE VI}

A comparison of the abilities of C. parvum and Bord. pertussis to induce anaphylactic sensitisation to horse serum in mice*

\begin{tabular}{|c|c|c|c|c|c|c|c|c|}
\hline \multicolumn{7}{|c|}{$\begin{array}{l}\text { The time of administration of the test agent }(X) \text { in } \\
\text { relation to time (days) from priming and challenge } \\
\text { doses of horse serum antigen (HS) }\end{array}$} & \multicolumn{2}{|c|}{$\begin{array}{l}\text { Number of survivors per group } \\
\text { of ten mice treated with the } \\
\text { stated agent }(X)\end{array}$} \\
\hline-14 & -7 & -4 & 0 & +4 & +7 & +14 & Bord. pertussis & C. parvum \\
\hline \multirow[t]{2}{*}{$x$} & $\mathrm{X}$ & $\mathbf{X}$ & $\begin{array}{c}\text { HS } \\
\text { HS } \\
\text { HS } \\
\begin{array}{r}\text { X+HS } \\
\text { HS } \\
\text { HS }\end{array}\end{array}$ & $\mathrm{X}$ & $\mathrm{x}$ & $\begin{array}{l}\text { HS } \\
\text { HS } \\
\text { HS } \\
\text { HS } \\
\text { HS } \\
\text { HS }\end{array}$ & $\begin{array}{r}10 \\
10 \\
6 \\
0 \\
10 \\
10\end{array}$ & $\begin{array}{l}10 \\
10 \\
10 \\
10 \\
10 \\
10\end{array}$ \\
\hline & & & HS & & & HS & \multicolumn{2}{|c|}{$10 \dagger$} \\
\hline
\end{tabular}

* Adult female Bromfield mice received X (C. parvum, 1.4 mg or Bord. pertussis, $0.22 \mathrm{mg}$ ) intravenously at the stated time intervals before, after or in combination with an intravenous priming dose of sensitising antigen HS (horse serum, $0.2 \mathrm{ml}$ diluted 1 in 5 in saline). Fourteen days after the priming dose, animals were intraperitoneally challenged with a second injection of horse serum $(0.2 \mathrm{ml}$ undiluted). Survivors were recorded at $24 \mathrm{hr}$, the majority of deaths occurring within $2 \mathrm{hr}$.

$t$ A control group of animals received two doses of horse serum but no injection of $X$. Animals from the same batch used in this experiment showed typical $C$. parvum sensitisation to histamine.

\section{Effect of C. parvum on anaphylactic sensitisation}

When administered together with an antigen, Bord. pertussis is able to induce anaphylaxis to a second injection of the same antigen (Malkiel and Hargis, $1952 a, b$ ). Experiments to investigate the possibility that $C$. parvum may behave similarly are shown in tables VI and VII. Bord. pertussis injected in combination with a priming dose of antigen produced maximal sensitisation when horse serum and ovalbumin were used as antigens. Lesser sensitisation was also observed when Bord. pertussis was injected 4 days before the priming dose of antigen. In experiments in which $C$. parvum was injected at varying times before, after or in combination with sensitising antigen, anaphylaxis could not be demonstrated.

The ability to be sensitised to histamine was not a prerequisite for anaphylactic sensitisation, because Olac mice (a strain only poorly sensitised to histamine by Bord. pertussis, table In) could be easily sensitised by the horse serum and Bord.pertussis procedure outlined. Moreover, results of tests with animals that received C. parvum alone are included in the data given in tables VI and VII 
and these findings confirm that there can be histamine sensitisation in the absence of concomitant anaphylactic sensitisation.

\section{Lack of induction of leucocytosis or lymphocytosis by C. parvum}

Since injections of killed Bord.pertussis cells and their extracts have frequently been shown to cause large increases in circulating white cell counts in recipient animals (Morse, 1965; Clausen, Munoz and Bergman, 1968), experiments were carried out to determine the effect of $C$. parvum on the numbers of circulating white cells. In agreement with the findings of others (McBride, 1971; Professor

TABLE VII

A comparison of the abilities of $C$. parvum and Bord. pertussis to induce anaphylactic sensitisation to ovalbumin in mice*

\begin{tabular}{|c|c|c|c|c|c|c|c|c|}
\hline \multicolumn{7}{|c|}{$\begin{array}{l}\text { The time of administration of the test agent }(X) \text { in } \\
\text { relation to time (days) from priming and challenge } \\
\text { doses of ovalbumin antigen (OV) }\end{array}$} & \multicolumn{2}{|c|}{$\begin{array}{l}\text { Number of survivors per group } \\
\text { of ten mice treated with the } \\
\text { stated agent (X) }\end{array}$} \\
\hline-14 & -7 & -4 & 0 & +4 & +7 & +14 & Bord.pertussis & C. parvum \\
\hline \multirow[t]{2}{*}{$\mathrm{X}$} & $\mathbf{x}$ & $\mathrm{x}$ & $\begin{array}{c}\text { OV } \\
\text { OV } \\
\text { OV } \\
\text { X+OV } \\
\text { OV } \\
\text { OV }\end{array}$ & $\mathbf{x}$ & $\mathbf{x}$ & $\begin{array}{l}\text { OV } \\
\text { OV } \\
\text { OV } \\
\text { OV } \\
\text { OV } \\
\text { OV }\end{array}$ & $\begin{array}{c}10 \\
10 \\
5 \dagger \\
3 \\
10 \\
10\end{array}$ & $\begin{array}{l}10 \\
10 \\
10 \\
10 \\
10 \\
10\end{array}$ \\
\hline & & & ov & & & ov & \multicolumn{2}{|c|}{10} \\
\hline
\end{tabular}

\footnotetext{
* Methods and routes of injections the same as for table VI except that ovalbumin (OV) was used as antigen ( $0.2 \mathrm{mg}$ priming dose, $1.0 \mathrm{mg}$ challenge dose).

$\dagger$ Only nine mice in this test group.
}

Sir Michael Woodruff, personal communication), a significant increase in the numbers of circulating white cells was not observed.

\section{Effect on adrenals}

Adrenalectomised mice are sensitised to histamine, serotonin, anaphylaxis and other stresses (Halpern, 1952; Munoz and Schuchardt, 1954). The possibility existed that treatment with $C$. parvum was producing sensitisation by exerting a toxic effect on the adrenals of recipient animals. Although tests for adrenal function were not carried out, no evidence of damage or altered structure of the adrenals was detected histologically in animals that had received C. parvum.

\section{Nature of the active sensitising material}

Although purification of the histamine-sensitising factor from C. parvum has not been undertaken during the present work, preliminary studies on the material have demonstrated a remarkable stability to physical and chemical agents. Table VIII gives the results of an experiment in which $C$. parvum was treated in various ways and the resulting suspensions examined for histaminesensitising activity. After the various treatments, C. parvum cells were washed 
and resuspended in physiological saline before injection. Sensitising activity was unaffected by exposure of the cells to wet heat at $80^{\circ} \mathrm{C}$ for $30 \mathrm{~min}$. and only slightly reduced after wet heat treatment at $100^{\circ} \mathrm{C}$ for $30 \mathrm{~min}$. Material incubated for $1 \mathrm{hr}$ at $37^{\circ} \mathrm{C}$ in Sørensen's glycine buffer (Sørensen, 1909; Sørensen, 1912) at $p H 11 \cdot 1$ remained fully active; after the same incubation at $p H 1.6$ it was partially active. The activity was also resistant to treatment with 2 per cent. formaldehyde. Treatment of $C$. parvum with formalin and with acidic or alkaline buffers caused aggregation of the resulting material and this caused some mortality on injection.

Table VIII

The stability of the histamine-sensitising factor of C. parvum to chemical and physical agents*

\begin{tabular}{l|c} 
Treatment of $C$. parvum & $\begin{array}{c}\text { Numbers of mice surviving } \\
\text { out of numbers subsequently } \\
\text { challenged }\end{array}$ \\
\hline Wet heat at $80^{\circ} \mathrm{C}$ for 30 min. (neutral $p \mathrm{H}$ ) & $1 / 10$ \\
Wet heat at $100^{\circ} \mathrm{C}$ for 30 min. (neutral $p \mathrm{H}$ ) & $4 / 10$ \\
Incubation at $37^{\circ} \mathrm{C}$ at $p \mathrm{H} 1.6 \mathrm{for} 1 \mathrm{hr}$ & $3 / 8 \dagger$ \\
Incubation at $37^{\circ} \mathrm{C}$ at $p \mathrm{H} 11.1 \mathrm{for} 1 \mathrm{hr}$ & $1 / 5 \dagger$ \\
Formaldehyde 2 per cent. at room temperature overnight & $0 / 8 \dagger$ \\
None & $0 / 10$ \\
Saline control & $9 / 10$
\end{tabular}

* Female adult Bromfield mice received a single intravenous injection of killed $C$. parvum that had been subjected to one of the stated treatments. Animals were intraperitoneally challenged at 7 days by histamine phosphate (1 mg base per mouse). Survivors were recorded at $24 \mathrm{hr}$.

+ Some deaths occurred after injection of $C$. parvum in these groups (see text).

\section{Discussion}

The present work has shown that $C$. parvum possesses histamine-sensitising properties very similar to those that have previously been considered unique for Bord. pertussis (with the possible exception of Brucella abortus, as reported by Malkiel and Hargis, 1958). Strains of mice that can be strongly sensitised to histamine by Bord. pertussis can also be strongly sensitised by $C$. parvum, and strains that do not respond to Bord. pertussis are refractory to sensitisation by C. parvum. Individual mouse strains do, however, show differences in their histamine-sensitisation patterns. Thus strain Balb $\mathrm{C}$ which was sensitised to some extent by Bord. pertussis was not sensitised at all by $C$. parvum. In these experiments fixed sensitising doses of $C$. parvum $(1.4 \mathrm{mg})$ and Bord. pertussis $(0.22 \mathrm{mg})$ were used. For $C$. parvum, this dose was considerably higher than that needed to sensitise (Adlam and Scott, 1973) and was chosen to ensure that failure to sensitise a given mouse strain could not be ascribed to an insufficient dose of organisms. A direct quantitative comparison on a weight for weight basis of the histamine-sensitising activities of the two organisms remains to be carried out when a histamine-sensitising factor from $C$. parvum has been chemically purified.

Previous workers have shown that Bord. pertussis produces optimal 
sensitisation to histamine when injected i.v. or i.p. The subcutaneous route is less effective (Munoz and Bergman, 1968). The present results show that C. parvum behaves similarly; in general it appears that C. parvum produces its most profound lymphoreticular stimulatory effects when injected intravenously rather than subcutaneously. Thus, increases in the weights of spleen and liver (simple measures of $C$. parvum lymphoreticular stimulating activity) and antitumour effects are much less marked when $C$. parvum is given by the subcutaneous route (Adlam and Scott, unpublished; Professor Sir Michael Woodruff and Miss Noreen Dunbar, personal communication).

With several mouse strains, Bord. pertussis sensitisation to histamine is greater in older mice than in younger ones (Kind, 1953; Bergman and Munoz, 1964). This phenomenon is also a property of C. parvum sensitisation to histamine and was apparent with both mouse strains examined.

Some mouse strains show a bimodal response to histamine; this has been observed in studies of animals treated with Bord. pertussis (Munoz, Schuchardt and Verwey, 1954) and in studies of untreated mice that received histamine without prior sensitisation (Townley, Trapani and Szentivanyi, 1967). Both of these observations have been confirmed with Bord. pertussis in the present work and C. parvum has been shown also to produce a bimodal response to histamine in young Bromfield mice.

Bord. pertussis produces sensitisation to serotonin as well as to histamine (Munoz, 1957; Kind, 1957; Kallós and Kallós-Deffner, 1957; Pittman, 1957). When serotonin sensitisation was tested in comparative studies with $C$. parvum and Bord. pertussis in the two mouse strains that had proved to be most easily sensitised to histamine, an important difference was apparent. Sensitisation was only achieved in one of these mouse strains with a large dose of $C$. parvum whereas both were sensitised by Bord. pertussis. In contrast to the findings with histamine sensitisation, serotonin sensitisation could only be demonstrated when bacteria of either species were injected intraperitoneally.

The most significant difference between C. parvum and Bord. pertussis sensitisation is the failure of $C$. parvum to elicit anaphylaxis when horse serum and ovalbumin are used as sensitising antigens. This demonstrates that histamine sensitisation and anaphylactic sensitisation can occur independently and adds weight to the argument that different mechanisms are involved. Munoz and Bergman have emphasised that differences exist in the kinetics associated with these two phenomena. Also it is known that antihistamine treatment, which may protect against Bord. pertussis-induced histamine sensitisation, does not necessarily protect against Bord. pertussis-augmented anaphylaxis (Malkiel and Hargis, 1952c). Moreover, Arora and Sanyal (1968) have concluded that a blockade of $\beta$-adrenergic receptors by Bord. pertussis does not explain the potentiating effect of the organism in anaphylaxis.

Unlike Bord. pertussis, C. parvum does not induce an increase in the numbers of circulating leucocytes and lymphocytes. This finding is in agreement with the conclusions of other workers (Clausen, Munoz and Bergman, 1968) and demonstrates that the ability to produce a leucocytosis or lymphocytosis is not a necessary requirement for histamine sensitisation. 
Most workers agree that Bord. pertussis produces its various sensitisation reactions by blockading either directly or indirectly the $\beta$-receptors of the adrenergic system. Preliminary results reported here suggest that the sensitising material from $C$. parvum is chemically different from that of Bord. pertussis which is known to be destroyed by heat or by treatment with formaldehyde (Munoz and Bergman). This means that any postulated common action of the two organisms on the $\beta$-adrenergic receptors must be indirect, since a direct action would demand that the organisms possess similar or identical sensitising components.

If both organisms are exerting an indirect action on the $\beta$-adrenergic receptors, how could this be brought about? Stimulation of the lympho-reticular system by a variety of agents including Bord. pertussis and $C$. parvum amplifies immune responses and causes activation and proliferation of macrophages with concomitant hyperplasia of lymphoid tissue. Stimulated animals are frequently sensitised to endotoxin. BCG (Bordet, 1936; Suter, Ullman and Hoffman, 1958; Halpern et al., 1958), zymosan (Benacerraf, Thorbecke and Jacoby, 1959), C. parvum (Howard, 1968), Bord. pertussis (Parfentjev, 1954; Kind, 1959), and a variety of other micro-organisms (see Suter and Kirsanow, 1961) produce this sensitivity. Animals in which a graft-versus-host reaction has been induced are similarly sensitised (Howard, 1961). Although the reasons for this sensitisation are not clear, challenge with endotoxin causes large amounts of lysosomal enzymes to be released into the circulation presumably from macrophages already rendered fragile by pre-treatment (Saito and Suter, 1965a, b; Howard, 1968). Such a release of lysosomal enzymes may prove to be important in histamine sensitisation by Bord. pertussis and $C$. parvum, and some lysosomal component possibly acts to blockade the $\beta$-adrenergic receptors. Alternatively, the release of lysosomal enzymes may have a direct action on histamine levels since Kelly et al. (1971) have demonstrated that injections of leucocyte lysates containing lysosomal enzymes cause histamine release in vivo.

\section{SUMMARY}

C. parvum resembled Bord. pertussis in being able to sensitise mice to histamine. Strains of mice that were strongly sensitised to histamine by Bord. pertussis were also strongly sensitised by $C$. parvum, whereas mouse strains that did not respond to Bord. pertussis were refractory to sensitisation by $C$. parvum. Other similarities between sensitisation produced by the two organisms included a dependence on mouse age and a tendency in some strains to produce a bimodal response to histamine following sensitisation. Both $C$. parvum and Bord. pertussis were capable of sensitising mice of one strain to serotonin, but sensitisation of another mouse strain to serotonin was produced only by Bord. pertussis and not by $C$. parvum.

Unlike Bord. pertussis, $C$. parvum did not augment anaphylaxis to heterologous antigens, nor did it produce leucocytosis and lymphocytosis in mice. Preliminary studies of the stability of the sensitising agent suggest that it is chemically different from the histamine-sensitising factor of Bord.pertussis. 
I am grateful to Dr J. Cameron, Dr P. Novotny and Dr J. G. Howard for discussion and helpful criticism of the manuscript. In addition, I thank Sheila Hiorns and Wendy Pearce for their capable technical assistance.

\section{REFERENCES}

Adlam, C., Broughton, E. S., AND Scott, M. T. 1972. Enhanced resistance of mice to infection with bacteria following pre-treatment with Corynebacterium parvum. Nature, New Biol., 235, 219.

ADlaM, C., AND ScotT, M. T. 1973. Lympho-reticular stimulatory properties of Corynebacterium parvum and related bacteria. J. Med. Microbiol., 6, 261.

ARora, S., AND SANYAL, R. K. 1968. The role of the adrenergic system in the mechanism of action of Bordetella pertussis vaccine. Int. Archs Allergy Appl. Immun., 33, 299.

BENACERRAF, F., THORBECKE, G. J., AND JACOBY, D. 1959. Effect of zymosan on endotoxin toxicity in mice. Proc. Soc. Exp. Biol. Med., 100, 796.

Bergman, R. K., AND MunOz, J. 1964. Histamine sensitivity in mice of different ages after Bordetella pertussis treatment or adrenalectomy. Proc. Soc. Exp. Biol. Med., 117, 400.

Bergman, R. K., AND MunOz, J. 1968. Action of the histamine sensitizing factor from Bordetella pertussis on inbred and random bred strains of mice. Int. Archs Allergy Appl. Immun., 34, 331.

Bordet, P. 1936. Contribution a l'étude de l'allergie. L'allergie non spécifique. Annls Inst. Pasteur, Paris, 56, 325.

Clausen, C., Munoz, J., AND Bergman, R. K. 1968. Lymphocytosis and histamine sensitization of mice by fractions from Bordetella pertussis. J. Bact., 96, 1484.

Fishel, C. W., SzentivanYI, A., AND TAlmage, D. W. 1964. Adrenergic factors in Bordetella pertussis induced histamine and serotonin hypersensitivity of mice. In Bacterial endotoxins, edited by M. Landy and W. Braun, New Brunswick, N.J., p. 474.

Gulbenkian, A., Schobert, L., Nixon, C., And Tabachnick, J. I. A. 1968. Metabolic effects of pertussis sensitization in mice and rats. Endocrinology, 83, 885.

HAlPERN, B. N. 1952. Histamine et antihistaminiques de synthèse. C. r. hebd. Séanc. Acad. Sci., Paris, 146, 1996.

Halpern, B. N., Biozzi, G., Howard, J. G., Stiffel, Claude, and Mouton, Denise 1958. Exaltation du pouvoir toxique d'Eberthella typhosa tuée chez la souris inoculée avec le BCG vivant. Relation entre cette augmentation de la susceptibilité et l'état fonctionnel du système reticulo-endothélial. C. r. Séanc. Soc. Biol., 152, 899.

halpern, B. N., Prévot, A-R., Biozzi, G., Stiffel, Claude, Mouton, Denise, Morard, J. C., BOuTHILlIER, YvoNNe, AND DÉCREuSEFond, CÉCILE 1964. Stimulation de l'activité phagocytaire du système reticuloendothélial provoquée par Corynebacterium parvum. J. Reticuloendothel. Soc., $1,77$.

HowARD, J. G. 1961. Increased sensitivity to bacterial endotoxin of $F_{1}$ hybrid mice undergoing graft-versus-host reaction. Nature, Lond., 190, 1122.

HowARD, J. G. 1968. Mechanisms concerned with endotoxin sensitivity during graft-versushost reaction. In La structure et les effets biologiques de produits bacteriens provenant de germes Gram-negatifs, edited by L. Chedid, Paris, p. 331.

Johnson, J. L., AND Cummins, C. S. 1972. Cell wall composition and deoxyribonucleic acid similarities among the anaerobic coryneforms, classical propionibacteria, and strains of Arachnia propionica. J. Bact., 109, 1047.

Kallós, P., ANd Kallós-DeffNer, Liselotte 1957. Effect of inoculation with $\boldsymbol{H}$. pertussis vaccine on susceptibility of albino mice to 5-hydroxytryptamine (serotonin). Int. Archs Allergy Appl. Immun., 11, 237.

Kelly, M. T., Brashear, R. E., Martin, R. R., and White, A. 1971. Histamine release in the dog after leukocyte lysate injection. Infect. Immun., 4, 228.

KIND, L. S. 1953. The altered reactivity of mice after immunization with Hemophilus pertussis vaccine. J. Immun., 70, 411.

KIND, L. S. 1957. Sensitivity of pertussis-inoculated mice to serotonin. Proc. Soc. Exp. Biol. Med., 95, 200. 
KIND, L. S. 1958. The altered reactivity of mice after inoculation with Bordetella pertussis vaccine. Bact. Rev., 22, 173.

KIND, L. S. 1959. Sensitivity of pertussis inoculated mice to endotoxin. J. Immun., 82, 32.

MCBride, W. H. 1971. Tolerance and adjuvants. Ph.D. Thesis, University of Edinburgh, Faculty of Medicine.

Malkiel, S., AND HARGIS, BetTy J. 1952a. Anaphylactic shock in the pertussis-vaccinated mouse. Proc. Soc. Exp. Biol. Med., 80, 122.

Malkiel, S., AND Hargis, Betry J. 1952b. Anaphylactic shock in the pertussis vaccinated mouse. II. Diphtheria and tetanus toxoids as antigens. Proc. Soc. Exp. Biol. Med., $81,109$.

Malkiel, S., AND HaRgis, BetTy J. 1952c. Anaphylactic shock in the pertussis-vaccinated mouse. J. Allergy, $23,352$.

MALKIEL, S., AND HARGIS, BeTTY J. 1958. Enhancement of histamine and anaphylactic shock in mice by Brucella abortus. J. Allergy, 29, 524.

MoRse, S. I. 1965. Studies on the lymphocytosis induced in mice by Bordetella pertussis. J. Exp. Med., 121, 49.

Munoz, J. 1957. Effect of $H$. pertussis on sensitivity of mice to serotonin. Proc. Soc. Exp. Biol. Med., 95, 328.

MunOz, J., AND BERGMAN, R. K. 1968. Histamine-sensitizing factors from microbial agents, with special reference to Bordetella pertussis. Bact. Rev., 32, 103.

MuNOZ, J., AND SCHUCHARDT, L. F. 1954. Sensitivity to histamine of adrenalectomized mice from different strains. J. Allergy, 25, 125.

Munoz, J., SChUChardT, L. F., AND VeRWEY, W. F. 1954. Studies on the sensitivity of mice to histamine following injection of Hemophilus pertussis. II. Effect of various substances upon histamine hypersensitivity. J. Allergy, 25, 120.

Niwa, M., YamadeYa, Y., Matsui, T., AND KuWaJma, Y. 1959. Reduced activity of histaminase in rats sensitized by Bordetella pertussis. Nature, Lond., 183, 755.

PARFENTJEv, I. A. 1954. Increased susceptibility to shigella endotoxin and to histamine after immunization to $H$. pertissis. Yale J. Biol. Med., 27, 46.

Pieroni, R. E., Bundeally, Amina E., Amdur, Mary O., ANd Levine, L. 1971. Bordetella pertussis as a beta-adrenergic blocking agent. Int. Archs Allergy Appl. Immun., 41, 637.

Pittman, Margaret 1957. Effect of Hemophilus pertussis on immunological and physiological reactions. Fed. Proc., 16, 867.

SArto, K., AND SuTER, E. 1965a. Lysosomal acid hydrolases in mice infected with BCG. J. Exp. Med., 121, 727.

SATTO, K., AND SUTER, E. 1965b. Lysosomal acid hydrolases and hyper-reactivity to endotoxin in mice infected with BCG. J. Exp. Med., 121, 739.

SHAYER, R. W., AND GANLEY, O. H. 1961. Relationship of increased histidine decarboxylase activity to Bordetella pertussis vaccine sensitization of mice. J. Allergy, 32, 204.

Sørensen, S. P. L. 1909. Biochem. Z., 21, 131 (abstracted in Documenta Geigy Scientific Tables, 6th ed., edited by K. Diem, Manchester, p. 314).

Sørensen, S. P. L. 1912. Ergbn. Physiol., 12, 393 (abstracted in Documenta Geigy Scientific Tables, 6th ed., edited by K. Diem, Manchester, p. 314).

Suter, E., AND KIrSANOW, EugenIA M. 1961. Hyper-reactivity to endotoxin in mice infected with mycobacteria. Induction and elicitation of the reactions. Immunology, 4, 354.

Suter, E., Ullman, Grace E., and Hoffman, R. G. 1958. Sensitivity of mice to endotoxin after vaccination with BCG (Bacillus Calmette-Guérin). Proc. Soc. Exp. Biol. Med., 99, 167.

Townley, R. G., Trapani, I. L., And Szentivanyi, A. 1967. Sensitization to anaphylaxis and to some of its pharmacological mediators by blockade of the beta adrenergic receptors. J. Allergy, 39, 177.

WARDLAW, A. C. 1970. Inheritance of responsiveness to pertussis HSF in mice. Int. Archs Allergy Appl. Immun., 38, 573. 